Reich, P. G. (1966). Analysis of long-range air traffic systems separation standards. This Journal, 19, 88, 169, 331 .

Stratton, A. (1969). Air traffic and navigation in the second half of the century. The Aeronautical Journal, 73,702 .

Automated traffic control for the U.K. Aerospace, March 1970.

\title{
PROFESSOR LEO BRANDT
}

It is with regret that we announce the death, on 26 April 1971, of Professor Leo Brandt, Honorary Life President of the Deutsche Gesellschaft für Ortung und Navigation and an Honorary Member of this Institute. Dr. Brandt had a distinguished scientific career and in various capacities made many contributions to the science of navigation. It was in the realm of international cooperation in navigation, however, that his achievements were most marked and a great deal of very fruitful work that the European Institutes between them have carried out was the result of early efforts of Dr. Brandt, with his collaborator General Wolfgang Martini, in drawing the Institutes together. 